\title{
A munkaidő, a pihenőidő és a szabadság új hazai szabályozásának megítélése a munka- vállalói érdekek szempontjából
}

\author{
napi munkaidő - rendkívüli munkavégzés ellenértéke - munkaidőkeret - \\ elszámolási időszak - az Európai Unió Bíróságának gyakorlata
}

\begin{abstract}
A téma időszerüségét és jelentőségét adja - ahogyan Zaccaria Márton Leó és Fodor T. Gábor is kimutatta -, hogy a munka- és a pihenőidő szabályai tekintetében a magyar jogi szabályozás túlnyomó része nem áll összhangban a jogintézmény kereteit szabályozó uniós joggal, az Európai Parlament és a Tanács, a munkaidő-szervezés egyes szempontjairól szóló 2003/88/EK irányelvével. ${ }^{1}$ Ez egyébként már a harmadik irányelv, amely e jogterületet „a munkaidő-szervezés egyes szempontjai” megjelöléssel rendezi. Az első, hasonló címet viselő irányelv a Tanács 93/104/EK irányelve (1993. november 23.) a munkaidő-szervezés egyes szempontjairól volt, amelyet követett az Európai Parlament és a Tanács 2000/34/EK irányelve (2000. június 22.) a munkaidő-szervezés egyes szempontjairól szóló 93/104/EK tanácsi irányelvnek az abból kizárt ágazatok és tevékenységek szabályozása céljából történő módosításáról, amelyet három év múlva felváltott a már említett 2003/88/EK irányelv. E két utóbbi irányelv azonban nem helyezte hatályon kívül teljesen az első irányelvet, bizonyos alapvető rendelkezései továbbra is hatályban maradtak. ${ }^{2}$

A témakört érintő, alapvető fogalmakat illetően a Munka Törvénykönyvéről szóló 1992. évi XXII. törvény (a továbbiakban: korábbi Mt.) szabályai már az első irányelvvel sem voltak összhangban. Ugyanakkor viszont a magyar jogalkotás mind a korábbi Mt. módosításaival, mind pedig a Munka Törvénykönyvéről szóló 2012. évi I. törvénnyel (a továbbiakban: új Mt.) érvénybe léptetett új Mt.-vel követte a két utóbbi irányelv azon új szabályait, amelyek az első irányelvhez képest a munkavállalók hátrányára és a munkáltatók javára módosították az első irányelvet. Sőt több vonatkozásban az irányelv intencióival és a régi tagállamok szabályozásával szemben szigorúbb elöírásokat vezetett be az új Mt., ami elsősorban a túlmunka és a rendkívüli munkavégzés lehetőségének a növelésében, valamint a túlmunka és a
\end{abstract}

* Dr. Prugberger Tamás professor emeritus, Miskolci Egyetem Állam és Jogtudományi Kar Agrárjogi és Munkajogi Tanszék, prugberger.tamas@t-online.hu.

1 ZACCARIA Márton Leó: Fogalmi változások a munkaidő kapcsán az új munka törvénykönyvében. Miskolci Jogi Szemle, 2013/1, 130-142; FODOR T. Gábor: A Munka Törvénykönyve munka- és pihenőidő szabályozásának uniós jogi megfelelőségéről. Magyar Munkajog E-folyóirat, 2016/2, 21-36.

2 2003/88/EK irányelv, preambulum (1) bek. 
rendkívüli munkavégzés után járó bérpótlékok csökkentésében, sőt a munkáltató egyoldalú döntésével a bérpótlékot szabadidővel történő kiváltásában jelentek meg. Ugyanakkor az új Mt. - általános jelleggel - a korábbi Mt. szerinti kivételes szabályt felülírva, a munkaidő mértékét az irányelvvel összhangban rendezte.

A téma aktualitását adja, hogy szóba került az irányelvben megállapított referencia-időszaknak - a munkaidőkeretnek - a további hosszabbitása egy munkaadó (a Bosch csoport) kívánságára. E törvénymódosítási javaslat már az Országgyülés Törvény-előkészítő Bizottsága elé került, azonban a kormány a szakszervezetek és a munkavállalók kemény ellenállása miatt visszavonta azzal, hogy a szociális partnerekkel az Mt. általános felülvizsgálata során újból megtárgyalja. ${ }^{3}$

Ezekkel a problémákkal a tervezet ismeretében már foglalkoztam. ${ }^{4}$ Most viszont az új Mt. hatálybalépése óta bevezetett módosításokat is figyelembe véve, a ma hatályos szöveg, valamint Zaccaria Márton Leó és Fodor T. Gábor jogdogmatikai fejtegetéseinek, ${ }^{5}$ továbbá Zaccaria Márton Leónak és Sipka Péternek az Európai Unió Bírósága e témát érintő ítélkezési gyakorlatát feldolgozó tanulmányának ${ }^{6}$ az alapul vételével vizsgálom meg az e téren fennálló hatályos jogot, összehasonlítást téve az uniós normákkal és a régi tagállamok megoldásaival.

\section{A témát érintő uniós normarendszer és a nyugat-európai tagállami megoldások}

A munkavállalók egészségvédelmére és munkaerejük regenerációjára az első irányelv volt a legnagyobb mértékben tekintettel. A 93/104/EK irányelvet még a szociális piacgazdaság és a „welfare society” szelleme, vagyis a keynesi gazdaságfilozófia hatotta át. Mindehhez hozzájárult a hetvenes évek gazdasági válsághulláma, mely felértékelte a szociális kérdések, így a munkajogi szabályozás szerepét. Az első Szociális Akcióprogram keretében 1975-ben Ajánlás született a 40 órás munkahétről és a négyhetes fizetett szabadság tárgyában. Majd az első munkaidőirányelv (93/104/EK) a heti munkaidő felső határát összességében 48 órában állapította meg. Ennek megfelelően az EK-tagállamok, de ugyanígy Magyarország esetében a régi $M t$. is a munkaidőt rendes és rendkívüli munkaidőre osztotta. A heti 40 órát meghaladó munkaidőre, valamint a heti pihenőidőben folytatott munkavégzésre az ajánlás pótlékfizetést javasolt, amelyet az egyes tagállamok munkajogi előírásai általában a munkanapokon a 8 órát meghaladó munkavégzésnél az alapmunkadíj felének megfelelő pótlékkal, a heti pihenőnapon, valamint a munkaszüneti napon végzett munka esetében pedig az alapmunkadíj megduplázásával honorálták.

3 http://www.hirportal.com (2017. 05. 27.).

4 Prugberger Tamás: A munkaidő, a pihenőidő és a szabadság várható új magyar jogi szabályozásának kérdéseihez. Jogtudományi Közlöny, 2011/11, 539-543.

5 Lásd az 1. sz. jegyzetet.

6 SIPKA Péter - ZACCARIA Márton Leó: Dolgozik és pihen? A munkaidő fogalmának bővítése az Európai Unió bíróságának újabb ítélete nyomán, tekintettel a magyar bírói gyakorlatra. Jogtudományi Közlöny, 2016/9, 449-457. 
A munkavállaló azonban kérhette, hogy a munkáltató a pótlék helyett, vagy felére csökkentett pótlékkal, a rendkívüli munkavégzéssel időarányos szabadidőt biztosítson. A hétköznapi túlmunka esetében ilyen kérelemnél az előbbire, míg a heti pihenőnapon és pihenőidőben, valamint a munkaszüneti napokon történő munkavégzésnél az utóbbira kerül sor. A közép- és kelet-európai (egykori) szocialista országok is így jártak el egyébként a politikai rendszerváltások előtt, illetve azt követően, ami véleményem szerint Magyarországra teljes körüen az új Mt. hatálybalépéséig volt igaz, mivel a pihenőnapon végzett munkavégzés szabályozása megváltozott: vasárnapi munkavégzés esetében fixen $50 \%$-os pótlék jár. ${ }^{7}$

Ezt követően, ahogy J. M. Keynes jóléti társadalmi és szociális piacgazdasági koncepcióját ${ }^{8}$ kezdte kiszorítani a globalizációval előtérbe kerülő, neoliberális gazdaságpolitika, ${ }^{9}$ felvetődött a heti munkaidőnek 48 óráról 60, majd 58 órára történő felemelésének az igénye a Munkáltatók Európai Szövetsége (UNICE) és az Állami Vállalatok Európai Központja (CEEP) részéről, aminek viszont a Szakszervezetek Európai Szövetsége (ETUC) ellenszegült. A kompromisszum eredménye lett a 2000/34/EK irányelv, mely lehetővé tette a munkaidőnek heti 58 órára történő felemelését, 2005-re azonban vissza kellett volna állni a heti 48 órás munkaidőre, oly módon, hogy 3 év után a heti munkaidőt 56 órára, a további két évben pedig 48 órára le kell szállítani. Ahogyan közeledett a harmadik évi időpont, az UNICE és az ETUC ismét a heti 48 órás munkahét véglegesítésének az igényével lépett fel. Azonban az ETUC-nak sikerült elérni, hogy erre ismét és csak utoljára 5 évre szólóan kerüljön sor, és véglegesen visszaálljon a heti 48 órás munkahét. Ezt rögzítette a jelenleg is hatályos 2003/88/EK irányelv. Ugyanakkor a munkáltatók javára mégis hagyott egy kiskaput azzal, hogy kimondja, hogy igen nyomós gazdasági indok vagy technológiai körülmény esetén kollektív szerződéssel fel lehet emelni - a már említett mértékig - 48 órát meghaladóan is a heti munkaidőt. Ezen túlmenően pedig a munkáltató a munkavállalóval legfeljebb 6 hónapig tartó időtartamra olyan megállapodást köthet, aminek alapján 48 órát meghaladóan, szintén a fent már említett mértékig, de rendes munkaidőben dolgozzon. Az irányelv 5. és 6. cikke, visszautalva a 94/104/EK irányelv hatályban tartott 1. és 2. cikkére, valamint a Tanácsnak a fiatal személyek munkahelyi védelméről szóló 94/33/EK irányelve (1994. június 22.) munkaidőt szabályozó 8-10. cikke lehetőséget ad arra, hogy amennyiben a munkaidő

7 Lásd 1992. évi XXII. törvény 147-148. §, 2012. évi I. törvény 139-143. §. Vesd össze Jura Europae, Droit du travail: Arbeitsrecht. C. H. Beck, München, Berlin, Edition Technique luris Chasseurs, Paris. Droit du travail, congres annuels. Arbeitzeit, Urlaub címszavak alatt az alábbi 9 tagállam megoldását I. Vol/Band: D., B., Fr. II. Vol/Band: I.,L., NL. III. Vol/Band:DM. Ir.Land., GB.; Hennsler/Braun: Arbeitsrecht in Europa, 3. Aufl. Verlag Dr. Otto Schmidt, Köln, 2011. L. országonként „Arbeitzeit” címszó alatt. Valamennyi közép-kelet-európai országban a munkapótlékra vonatkozó keretszabályozás alapján e kérdést a kialakult gyakorlat alapján ilyeténképpen firma-tarifaszerződések, üzemi munkarendek és/vagy üzemi megállapodások rendezik.

8 KeYNES, John Maynard: A foglalkoztatás, a kamat és a pénz általános elmélete. Közgazdasági és Jogi Könyvkiadó, Budapest, 1965.

9 HAYEK, Friedrich: Piac és szabadság. Közgazdasági és Jogi Könyvkiadó, Budapest, 1995; Friedman, Milton: Kapitalizmus és szabadság. Akadémiai Kiadó, Budapest, 1996; MARtıN, Hans-Peter-SchumanN, Harald: A globalizáció csapdája. Perfekt Kiadó, Budapest, 1998. 
a heti 40 órát meghaladja, a túlmunkát és a rendkívüli munkát a tagállami előírások külön honorálják. ${ }^{10}$

A 2000/34/EK irányelv elött is megvolt a lehetőség arra, hogy „referencia-időszakot", vagyis munkaidőkeretet megállapitva, és meghatározott időszak leteltét követően átlagolva fizessék ki a munkáltatók a munkavállalók által végzett rendkívüli munkát. Ez az egyes régi tagállamok esetében átlagosan egy-két hónapos időszakot jelentett, és jelent a legtöbb helyen ma is. A 2000/34/EK irányelv ezt a referencia-időszakot 4 havi időtartamra hosszabbította meg, amit kollektív szerződéssel 6 hónapra engedett kiterjeszteni. A ma hatályos irányelv ugyanakkor a referencia-idöszakot egységesen 6 hónapos időtartamban állapitotta meg. A referencia-időszak egyre hosszabbá tételével a túlmunka és a rendkívüli munka heti és havi korlátai kezdtek feloldódni, illetve megszűnni.

A rendkívüli munkavégzés esetei közül neuralgikusnak számít még a készenlét és az ügyelet. A készenlétet - ami azt jelenti, hogy a munkavállaló a munkahelyén kívül bárhol tartózkodhat, azonban munkába állás végett a munkáltató által elérhetőnek kell lennie - sem az európai munkajog, illetőleg az európai bírósági ítélkezési gyakorlat, sem a tagállamok munkajoga nem tartja munkaidőnek, és ezért nem is díjazza. Ezzel szemben az ügyeletet rendkívüli munkaidőnek, illetve munkavégzésnek tekintetik a nyugat-európai államok munkajogi szabályai, és ezért korábban, mintegy rendkívüli munkaként általában a munkabér 50\%-át kitevő pótlékkal honorálták. ${ }^{11}$ Ugyanakkor az USA munkajogában a Portal to Portal Act of 1947 az ügyeletet - amit mindenhol a munkahelyen kell teljesíteni - rendes munkaidőként kezeli, és annak megfelelöen is dijjazza. ${ }^{12}$ Ezt is figyelembe véve mondta ki egységesen az Európai Unió Bírósága több ítéletben, hogy az ügyeletet rendes munkaidőként kell elbírálni. ${ }^{13}$ Eme európai bírósági ítéletek hatására az EU nyugat-európai tagállamai először legfelső szintủ bírósági elvi állásfoglalással, majd pedig tételes jogilag is a rendes munkaidőnek megfelelően állapították meg az ügyeleti idő maximumát, kimondva azt is, hogy az ügyeletre is a rendes munkabér jár. ${ }^{14}$ Mindezt a 2003/88/EK irányelv 2. cikke alapozta meg, amely a munkaidő fogalmát mindvégig úgy határozta meg és határozza meg most is, hogy azt az időt is munkaidőnek kell tekinteni, amikor a munkavállaló nem dolgozik, de a munkáltató rendelkezésére áll. ${ }^{15}$

10 2003/88/EK irányelv 5-6. cikke alapján 93/104/EK irányelv 1. cikk b) pont és 2. cikk (4) bekezdése, valamint 94/33/EK irányelv 9. cikke. Lásd még PRUgBerger Tamás - JaKAB Nóra - ZACCARIA Márton Leó: Az európai munkajog vázlata. Lícium Art Könyvkiadó, Debrecen, 2016, 59.

11 Prugberger Tamás-Tóth Hilda: A munkaidő, a pihenőidő, a szabadság és a túlmunka munkajogi kérdései. Valóság, 2001/1, 24-26.

12 Prof. Marley Weisstől, a Marylandi Egyetem Jogi Karának munka- és szociális jogi tanárától kapott információ, Budapest, 2001.

13 C-303/98 sz. Sindicato de Médicos de Asistencia Pública (Simap) v Conselleria de Sanidad y Consumo de la Generalidad Valenciana ügyben (Simap-ügy) 2000. október 3-án hozott ítélet (ECLI:EU:C:2000:528); C-151/02. sz., Landeshauptstadt Kiel v Norbert Jaeger ügyben (Jaeger-ügy) 2003. szeptember 9-én hozott ítélet (ECLI:EU:C:2003:437); RADNAY József: Újabb külföldi döntés a heti 48 órát meghaladó munkaidő számítás tárgyában. Munkaügyi Szemle, 2006/78, 89-90.

14 Prugberger Tamás: A munkaerő-átirányítás egyes jogdogmatikai problémái. Magyar Jog, 2005/8, $458-464$.

15 2003/88/ EK irányelv 2. cikk, 1. pont. 
Ez volt az eredeti definíció, amit a 93/104/EK irányelv 2. cikke fogalmazott meg. A 2000/34/EK és a 2003/88/EK irányelveknek szintén a 2. cikke alapján azonban némi módosulás, illetve kiegészítés következett be, mivel ezek munkaidőnek azt az időt tekintik, amely alatt „a munkavállaló dolgozik, a munkáltató rendelkezése alatt áll és tevékenységét vagy feladatát végzi a nemzeti jogszabályoknak és vagy gyakorlatnak megfelelően”. Pihenőidő pedig az irányelv szerint az, „amely nem minősül munkaidőnek". Megítélésem szerint a munkaidő új definíciója nyelvtani értelmezés mellett szükebb a korábbinál, mégpedig amiatt, mert az „és” szó következtében nem elég a rendelkezésre állás, hanem a 2003/88/EK irányelv 2. cikke 1. pontjának új szövege a rendelkezésre álláshoz kapcsolja a nemzeti jogszabályok szerinti feladat, illetve tevékenység végzését is.

E megfogalmazás a munkavállalók számára hátrányos és igazságtalan. Szigorú értelmezés mellett ugyanis nem járna a munkavállalók számára munkabér olyan esetekben, amikor akár külső ok miatt, akár pedig a munkáltatónak felróhatóan vagy az érdekkörébe tartozó oknál fogva nem tudnak az egyébként a munkahelyen készen álló munkavállalók dolgozni. Ilyen ok lehet, ha pl. az áramszolgáltatás a közmü meghibásodása miatt kimarad, vagy nem érkezik meg a feldolgozandó nyersanyag. Ezt a problémát nyilván észlelte az Európai Unió Bírósága is, az amerikai Portal to Portal Acthoz hasonlóan munkaidőnek tekinti azt az időt is, amikor a munkavállaló nem dolgozik, de a munkahelyén van, és a munkáltató rendelkezésére áll. ${ }^{16}$

Ezen túlmenően az irányelv szigorú nyelvtani értelmezésével szemben az Európai Unió Bírósága - miként erről Fodor T. Gábor és a Sipka-Zaccaria szerzőpáros beszámol - munkaidőnek tekinti az olyan munkahelyen kívüli tartózkodást is, amikor a munkavállaló a meghatározott munkavégzési cél teljesítése érdekében a munkáltató utasítása szerint van úton, akkor is, ha az meghaladja a távolságot és a cél eléréséhez indokolt menetidőt. Ennek a leggyakoribb esete, amikor a munkavállaló a lakásától, illetve szokásos tartózkodási helyétől nem a munkáltató telephelyére, hanem pl. kereskedelmi utazóként vagy karbantartóként az első ügyfélhez, illetve az utolsótól a lakó-, illetve pihenőhelyéhez megy. ${ }^{17}$ Ugyanígy munkaidőnek kell tekinteni most és korábban egyaránt azt az időt is, amelyet a munkavállaló vagy a feladatai teljesítése céljából helyi vagy helyközi közlekedéssel megtesz, vagy ha ilyen utazás közben az országhatáron esetleg várakoznia kell. A szolgálati út és az e közbeni kényszerü várakozás munkaidővé minősítéséhez nem férhet kétség. Ugyanez vonatkozik arra az esetre is, ha a munkavállalónak átirányítás, kiküldetés, helyettesítés vagy kirendelés, illetve más munkavállalónak történő haszon-kölcsönszerü átengedés miatt a „törzsmunkahelyétől” egy olyan munkahelyre kell mennie dolgozni, amely a lakóhelyétől, illetve pihenőidejének a szokásos helyétől távol esik, és az odautazás az állandó munkahelyéhez képest hosszabb időt igényel. ${ }^{18} \mathrm{Ez}$ azonban a változó munkahelyre kötött munkaszerződés esetére nem vonatkozik. Hasonlóképpen foglalt állást legutóbb az Európai Unió Bírósága a Tyco-ügyben. Ebben a

16 Prugberger Tamás-NÁdas György: Európai és magyar összehasonlító munka- és közszolgálati jog. CompLex, Budapest, 2014, 229-230; FodOR T.: i. m., 23-26.

17 FODOR T.: i. m., 24-26; SIPKA-ZACCARIA: i. m., III-V. rész.

18 Uo. 
2003/88/EK irányelv alapján pontosította a spanyol legfelsőbb bíróság megkeresésére a munkaidő és a pihenőidő fogalmát a kettőnek az egymástól való elhatárolásával. Eszerint a pihenőidő az, amit a munkavállaló a saját akarata szerint tölt el. Az olyan utazási idő, amelyet a munkáltató határoz meg, még ha nem is végez a munkavállaló munkát, rendes munkaidőnek számít, és a szerint is kell díjazni. ${ }^{19}$

A munkaidővel kapcsolatos európai uniós és tagállami normákkal összefüggésben szólni kell még az éjszakai ügyeletről, amelyet mind az 1993/104/EK, mind a 2000/34/EK irányelv és ugyanígy a 2003/88/EK irányelv is „expressis verbis” megemlít. Az éjszakai műszakot mindegyik az este 10 órától másnap reggel 6 óráig tartó munkavégzésben jelöli meg, amely időtartamba az éjfélnek és a reggel 6 órának bele kell esnie. ${ }^{20}$ Éjszakai müszakban dolgozó munkavállalónak az irányelv értelmében azt kell tekinteni, aki vagy állandóan éjszakai müszakban dolgozik, vagy ha váltott müszakban, akkor éjszakai munkája évi átlagban munkaidejének legalább az egyharmadát kiteszi. Az irányelvi szabályozás alapján alakulnak az egyes tagállamokban az éjszakai munkavégzés szabályai, így, aki állandó jelleggel éjszakás, müszakpótlékként alapmunkabére 15\%-át kapja meg, akinél pedig a nappali és az éjszakai műszakok váltják egymást, az egészséget megterhelő életritmusváltás miatt általában alapmunkadíja 30\%-át kapja meg pótlékként.

\section{A magyar szabályozásnál jelentkező problémák az uniós és a nyugat-európai tagállami normarendszer tükrében}

\subsection{A szabályozás jogi keretei}

A 2003/88/EK irányelv kimondja, hogy a hétnapos időtartamban az átlagos munkaidő nem haladhatja meg a 48 órát. ${ }^{21}$ Összevetve a referencia-időszakkal, vagyis a munkaidőkerettel, ez azt jelenti, hogy a munkaidőkereten belül, annak átlagában a munkaidő nem haladhatja meg a heti 48 órát. Azt a munkaidőkeret alatt ledolgozott órák összeadásával és az így megkapott összmunkaóra-mennyiségnek a munkanapok számával történő elosztásával lehet megállapítani, hogy a munkavállaló napi átlagban mennyi munkaórát dolgozott. A napi átlagnak öttel történő beszorzásával kijön az a munkaóraátlag, amennyit a munkaidőkereten belül heti átlagban dolgozott. Magyarországon a korábbi Mt. 117/B. §-a a 2005. évi módosítás előtt bizonyos esetekben (folyamatos üzemelés, többmüszakos munkarend, készenléti jellegü munka, munkavállaló a munkáltató hozzátartozója) lehetővé tette a napi 12, illetve heti 60 órás munkaidő alkalmazását. Ebből a 2005. évi módosítással, majd az új Mt. 92. §-ával mára csak a készenléti jellegű munkavégzés és a munkáltató, valamint a munkavállaló között fennálló hozzátartozói kapcsolat keretei közötti foglalkozta-

19 C-266/14. sz., Federación de Servicios Privados del sindicato Comisiones obreras (CC.OO.) v Tyco Integrated Security SL and Tyco Integrated Fire \& Security Corporation Servicios SA ügyben (Tyco-ügy) 2015. szeptember 10-én hozott ítélet (ECLI:EU:C:2015:578, ECLI:EU:C:2015:391).

20 Mindhárom irányelvben a 2 . cikk (3) bekezdés.

21 Az irányelv 6 . cikk b) pontja és a 22. cikk (1) bekezdés a) pontja. 
tás esete maradt meg, amikor lehetséges a napi 12 órás munkaidő alkalmazása. ${ }^{22}$ A zárójelben feltüntetett többi lehetőséget már a korábbi Mt. novellája megszüntette, és ma a munkaidő - összhangban az irányelv általános elöírásaival - fö szabályként heti 40 óra, ami a túlmunkával, illetve a rendkívüli munkavégzéssel, maximálisan 48 óta lehet. Ezt a munkanormát, Zaccaria Márton Leóval és Fodor T. Gáborral egyetértve, véleményem szerint sem munkaviszonyonként, hanem munkavállalónként kell érteni. ${ }^{23}$ Ebből adódóan akkor sem lehet több a munkaidő a munkaidőkeretben megállapított heti 48 óra átlagánál egy-egy munkavállaló esetén, amikor [az irányelv 17. cikk (1) bekezdése alapján] kollektív szerződéssel heti 48 óránál hosszabb munkaidő megállapítható, illetve amikor a munkavállalóval legfeljebb 6 hónapos időtartamra külön megállapodásban történő 48 órát meghaladó munkavégzésre kerül sor.

Itt mutatkozik meg annak a jelentősége, hogy mindezt nem az absztrakt munkaviszony, hanem az egyes munkavállalók alapulvételével kell figyelembe venni, a munkaerő regenerációjának biztositása érdekében. Különben ugyanis az éves szinten 250, illetve kollektív szerződéssel 300 munkaórára felemelhető túlmunkamaximum lenne az a felső határ, amelynek eléréséig bizonyos munkakörökben vagy munkaviszonyokban akár egyhuzamban, hónapokon keresztül lehetne a munkavállalót (a végkimerülésig) dolgoztatni, ami mellett a munkaerő a regenerálódásra könnyen képtelenné válhat, illetve a munkavállaló „kiéghet”.

Ezért lenne a munkavállalói jogok szempontjából meglehetősen veszélyes a munkaidőkeretnek a 3 évi időtartamban való meghatározása, amit a Bosch és még néhány Magyarországon müködő autógyártó cég kívánságára a kormány, a nyilvánosságra került információk szerint az Mt. módosításával meglépni szándékozik. ${ }^{24}$ A Bosch azzal érvel, hogy nála a termék elóállítása és a termelés felfuttatása hoszszabb időkeretet igényel, és ezért 3 év szükséges ahhoz, hogy a termék piacra kerülhessen. A cégcsoport e célkitüzését Németországban elérte, azonban nem a jogi szabályozásnak az egész országra kiterjedő módosításával, hanem kollektív szerződés útján, amibe a szakszervezet is beleegyezett, mivel az érintett munkavállalók munkabérét a munkáltató jelentősen emelte. ${ }^{25}$ Erről viszont Magyarország esetében szó sem esett. ${ }^{26}$ Azt még el lehet fogadni, hogy Németországhoz hasonlóan az érintett munkavállalók munkabérének jelentős emelése mellett kollektív szerződéssel

22 1992. évi XXII. törvénynek (korábbi Mt.) 2005. évi VIII. törvénnyel történő módosítás előtti és utáni 117/B. § (3) bek. és 2012. évi I. törvény (új Mt.) 92. § (2) bekezdése rögzíti a kifejtett szabályozást.

23 Zaccaria: i. m., 137; Fodor T.: i. m., 22.

24 Kormányberkekből a szakszervezeti vezetők részére kiszivárogtatott hír, amelyet 2017. május közepén napilapok is közöltek, és ami jelenleg is fennáll. Információ egybehangzóan a Liga és a Munkástanácsok elnökétöl.

25 Walter Wendt-Kleinbergtöl (Institut für Kirche und Gesellschaft der Evangelischen Kirche von Westfalen) kapott információ, a Friedrich Ebert Stiftung és a Friedrich Neuman Stiftung által, 2007. 05. 20-22. között rendezett, „Globalizierung und Gerechtigkeit” c. nemzetközi konferencián. Tételes jogi lehetőségét lásd FODOR T.: i. m., 22.

26 A munkaidőkeret 3 évre történő felemelését célzó Mt. módosítási tervet a kormány a szociális partnerekkel az Országgyűlés Törvény-előkészítő Bizottságához történt beterjesztése előtt nem egyeztette, kifelé pedig csak annyit közölt, hogy a Munka Törvénykönyv módosítási indítványát az Országgyűlésnek beterjesztette. A munkaidő-szervezés egyes kérdéseiről szóló T/15035. számú törvényjavaslatot a szakszervezetek egységes tiltakozásának hatására a kormány visszavonta. 
és csak a Boschnál bevezessék a 3 éves munkaidőkeretet. Ez ellen szól azonban az, hogy a Boschnál ilyen módon dolgozók regenerálódás nélkül maradnak. Ezen túlmenően a munkaidőkeretnek az irányelvben meghatározott felső határát meghaladó törvényi előírás az Európa-jogba ütközne. Az irányelvi felső határ pedig 6 hónap. Megítélésem szerint azonban ez munkaegészségügyi és munkaszociális szempontból is elfogadhatatlan lenne. Nem véletlen, hogy a nyugat-európai államok többségében a munkaidőkeret 4 hétnél általában nem több. ${ }^{27}$ Hasonló problémával állunk szemben a készenlét és az ügyelet szabályozásánál is. $E$ tanulmány előző részében már utalás történt Fodor T. Gábor munkája alapján arra, hogy az Európai Unió Bírósága a készenlétet nem kezelte eddig munkaidőnek, és ezért, ha erre kötelezte a munkavállalót a munkáltató, akkor nem fizetett érte munkadíjat. Ennél kedvezőbb a korábbival egyező, jelenleg hatályos új magyar Mt., amely szerint készenlét esetében a munkavállalót megilleti az alapbérének a 20\%-a. Viszont az ügyelet esetében a magyar Mt. korábban és most is - ellentétben az Európai Unió Bírósága ítélkezési gyakorlatával és a nyugat-európai tagállamok megoldásaival -, nem a teljes munkabért, hanem csak az alapmunkabér 40\%-át biztosítja. Emellett a magyar Mt. korábban és most is, az uniós normarendszerrel ellentétben, nem rendes, hanem rendkívüli munkaidőként kezeli az ügyeletet. Ez adja meg a lehetőséget arra, hogy az ügyelet meghaladhassa a heti 48 órát, ami akár 60 óra is lehet, az egészségügyben pedig elérheti a heti 72 órát is. ${ }^{28} \mathrm{Az}$ új magyar Mt. ugyanis a 2003/88/ EK irányelv 17. cikkének eltérési lehetőségét visszaélés-szerüen kihasználva, az ügyeletet az egészségügyben a tengeri halászhajókon dolgozók munkaidejének az analógiájára állapította meg. Ennek és az ügyelet nem rendes munkabérként történő megfizetésének is a következménye, hogy a magyar egészségügyben nagy a külföldre történő kivándorlás és a munkaerőhiány.

Egyetlen racionális megállapítás és következtetés szűrhető le mindebből, mégpedig az, hogy a magyar ügyelet fogalma és szabályozása teljesen ellentétes az Európai Unió Bírósága felfogásával. Az ügyeletet ugyanis az Európai Unió Bírósága álláspontjának megfelelően rendes munkaidőnek kell tekinteni és aszerint is kellene díjazni. Ezért nincs is szó az irányelvben az ügyeletről. Ennek hiányából adódóan, a jelenlegi szabályozás káros jogszociológiai és társadalmi feszültséget okozó következménye miatt, sürgősen összhangba kellene hozni az ügyelet hazai fogalmát és szabályait az irányelvi előírásokkal és a nyugat-európai gyakorlattal. Mindez azt jelenti, hogy az Mt. módosításával ki kellene mondani, hogy az ügyeletre a rendes munkaidőre vonatkozó szabályok az irányadóak a munkabérfizetés tekintetében is.

Ami pedig a készenlétet illeti, a mai magyar szabályozás jelenleg még kedvezőbb az uniós rendelkezésnél. Azonban szükséges megemlíteni, hogy az Európai Unió Bíróságának ítéleteiből kiolvashatóak arra való törekvések, hogy a készenlét is rendes munkaidővé nyilváníthatóvá váljon. Azokon a területeken, ahol ez megtörténne, indokolt lenne nemcsak munkajogelméleti, hanem munkaszociológiai és

27 Prugberger-Tóth: i. m., 22-26; Prugberger Tamás: Magyar munka- és közszolgálati reform európai kitekintéssel. Novotni Alapítvány, 2012, 83-87.

28 Barzó Tímea-Prugberger Tamás: Munkaidő-szervezés az egészségügyben az uniós és a hazai szabályozás tükrében. Új Magyar Közigazgatás, 2015/1, 25. és 27-28.; BARzó Tímea: Sham contract in the field of health care. Curentul Juridic, 2016/2,115-125. 
munkajog-politikai szinten is követni az európai bírósági gyakorlat alapján az esetleg megváltozó uniós norma változását is. Emellett azonban, ameddig erre nem kerül sor, továbbra is indokolt lenne a magyar szabályozásban az uniós jognál és a nyugat-európai nemzeti jogoknál kedvezőbb magyar szabályozást fenntartani a munkabéreknek a nyugat-európai államok átlagához viszonyított alacsonyabb szintje miatt.

\subsection{A referencia-időszak, a munkaidőkeret és az elszámolási időszak elhatárolása - a munkaidő, munkanap fogalma}

Az eddig zömében jogszociológiai és jogpolitikai megközelítésü elemzésemet kifejezetten jogdogmatikai értelmezéssel folytatom, mégpedig deduktív alapon. Először a referencia-időszak, a munkaidőkeret és az elszámolási időszak fogalmát és egymástól való elhatárolását szükséges tisztázni. Zaccaria Márton Leó szerint az irányelv „referencia-időszak” fogalma a magyar „elszámolási időszak” megfelelője. ${ }^{29}$ Ezt a szerző azzal indokolja, hogy munkaidőkeret nélkül is be lehet osztani a munkaidőt egyenlőtlenül. Ebben az esetben az adott hétre eső munkaidőt a munkavállaló a munkáltató által meghatározott hosszabb idő alatt teljesíti. Álláspontja szerint Nyugat-Európában ez jelenti a munkaidőkeretet. ${ }^{30} \mathrm{Az}$ ennél hosszabb munkaidőkeretet elsősorban az új tagállamok részére találták ki, tudva, hogy eme államokban az EU által megkívánt privatizáció lefolytatását követően a közép- és kelet-európai vállalatok zöme nyugat-európai érdekeltségbe került, és a hosszabb munkaidőkerettel a túlmunka és rendkívüli munka után járó pótlékot redukálni lehet. Ezt a körülményt figyelembe véve, a munkaidőkeret a referencia-időszakkal összhangban áll. Erre érez rá Fodor T. Gábor, aki szerint a munkaidőkeret egy kezdettel és egy véggel rendelkező elszámolási időszak. ${ }^{31}$ Az átlagszámítási időszak és maga az átlagolás egyértelműen a munkaidő-számításhoz, a munkaóra-referenciaperiódushoz, vagyis a munkaidőkerethez kapcsolódik. Az elszámolási időszak csak követi a munkaidőkereten kívüli és a munkaidőkereten belüli időben meghatározott tényleges munkavégzést, ami után elszámolásra kerül a munkabér. Ennélfogva, ha az elszámolási időszak érinti a munkaidőkeretet, vagyis a referencia-időszakot, és ha az „áttöri” a referencia-időszak kezdetét vagy a végét, a két időszak egymástól elcsúszhat. Ezért a kettőnek nem kell egymással összhangban állnia, vagyis a két időszak nem függ össze egymással. ${ }^{32}$ Ezt az álláspontomat erősíti meg az is, hogy időszakos elszámolás szükségszerüen akkor is fennáll, amikor nincs munkaidőkeret. Ebből a szempontból jó az Mt. megoldása, amely még összefüggést sem sejtet a referenciaidőszak és az elszámolási időszak között. ${ }^{33}$ Helyes lenne azonban, ha a félreértések elkerülése végett ezt az Mt. ki is nyilvánítaná.

29 ZACCARIA: i. m., 141.

30 FODOR T.: i. m., 29-32.

1 FODOR T.: i. m., 31-32.

32 FOdOR T.: i. m., 31-32.

33 A munkaidőkeretről az Mt.-nek a munkaidőről és a pihenőidőről szóló VI. fejezetének a 48. pontja beszél, míg a munkabérről szóló VII. fejezetben a 156. § (3) bekezdése említi az elszámolási időszakot a „vagy” kötőszóval egymástól elválasztva. 
Szükítve most a vizsgálatomat a munkaidőre, annak hazai fogalma látszólag teljesen más, mint amit az irányelv - a már ismertetettek szerint - megfogalmaz. Az Mt. 86. §-a értelmében munkaidő „a munkavégzésre előírt idő kezdetétől annak befejezéséig tartó idő, valamint a munkavégzéshez kapcsolódó előkészítő és befejező tevékenység tartama”. A fogalomalkotás logikáját nézve mintegy a külső, formális oldalról határozza meg az Mt. a munkaidőt, mégpedig a szűkebb munkavégzésre szánt részének kezdetét és végét egzaktul, az előkészítő és befejező tevékenység tartamát viszont a korábbi szabályozással szemben egzaktabbul. A 86. § (2) bekezdése ugyanis rögzíti, hogy az előkészítő és befejező tevékenységhez tartozik minden olyan feladat ellátása, amelyet a munkavállaló a munkaköréhez kapcsolódóan szokás szerint és rendszeresen külön utasítás nélkül köteles elvégezni. Ennek ellenére a munkáltatók jelentős része ma is az előkészítő és befejező tevékenységet „elfelejti” a munkaidőbe beszámítani, holott arra a magyar és az uniós jog alapján is köteles lenne, amihez a nyugat-európai gyakorlat tartja is magát. ${ }^{34}$

Ami már most a munkaidő „belülről” történő tartalmi fogalommeghatározását illeti, azt az irányelvi meghatározás adja. Ebben utalás történik arra, hogy amikor a munkavállaló a munkáltató részére rendelkezésre áll, az is munkaidő. Az Mt. fogalommeghatározásában csak a munkavégzésre történik utalás, a rendelkezésre állásról nem. Ugyanakkor viszont az Mt. quasi „keretfogalmába” belefér a rendelkezésre állás is. Ezt figyelembe véve indokolt lenne az Mt. 86. §-ában a munkaidőnek az Mt. által a külső oldaláról meghatározott fogalmát „belső oldalról” is kiegészíteni. Mégpedig úgy, hogy a munkaidő tartamába fogalmilag beletartozzon a munkavégzés és az olyan rendelkezésre állás is, ami a munkavégzéssel függ össze, amikor is a munkavállaló egy bizonyos időszakon belül rajta kívül álló ok miatt dolgozni nem tud, de a munkahelyen munkavégzésre rendelkezésre áll. Ebböl következik, hogy helyes lenne az Mt. munkaidő fogalmát az általam már említett pontosítás után öszszekapcsolni az irányelv fogalmával.

Az Mt. 87. §-a meghatározza a munkanap fogalmát is. A munkanap fogalmáról az irányelv nem tesz említést, csak több müszakról beszél. Mivel kimondja, hogy akkor áll fenn több müszak, amikor a napi munkaidő meghaladja a 8 órát, „a contrario” arra a következtetésre juthatunk, hogy az irányelv az egy müszakot fő szabályként 8 óra munkavégzésben állapítja meg. Arról viszont nem szól, hogy a több műszak hogyan viszonyul a munkanaphoz. Átlépheti-e a 24 órát vagy sem? Az Mt. 87. §-a viszont ebben egyértelmübb, mivel meghatározza a munkanapot, ami 24 óra, és fő szabályként a naptári naphoz igazodik. Ha viszont nem igazodik hozzá, akkor a munkanap a naptári naptól független, egybefüggő 24 munkaóra. Mind a kettőnél (a napi 8 órás munkaidőt, illetve a 8 órás müszakot figyelembe véve) Magyarországon egy munkanapba legfeljebb három múszak fér bele.

Ez a meghatározás a munkavállalók számára jobb, mint a „rugalmasabbnak” minősíthető irányelvi munkaidő-meghatározás. A magyar munkajog alapján, ha a munkáltató a munkanapon belül (a munkanapot kimerítő jelleggel) nem három, hanem két múszakos munkarendet állapít meg, akkor a napi munkaidő esetleg 12 óra időtartamú. Erre az Mt. 92. §-a lehetőséget ad. A napi munkaidő maximuma ugyanis 12 munkaóra, minimuma pedig 4 munkaóra lehet. Az Mt. szerint, ha - munkaidő keret

34 Az irányelv 2. cikkének 5. pontja alapján vezethető le. 
alkalmazásával - a 12 munkaórás munkanapok egy héten belül nem haladják meg a heti 40 órát, túlmunkapótlék nem jár. Ha viszont a heti 40 órát meghaladják, pótlék vagy a túlórák arányában szabadidő jár, formálisan a munkavállalók és a munkáltató megegyezése alapján. Ebben az esetben csak azt kell nézni, hogy a túlmunkák éves átlagban ne haladják meg az évi 250, kollektív szerződés esetében pedig a 300 munkaórát. Lényegében ugyanilyen munkavégzés lehetősége fennáll az irányelvi normarendszer alapján is. Sőt a magyar szabályozás az irányelvvel teljesen összhangban áll. A kettő között a különbség csupán az, hogy a magyar szabályozás egzaktabb és egyértelmúbb, mint az irányelvi szabályozás.

\subsection{A rendkívüli munkaidő kérdése}

Ez a kérdés átvezet bennünket a rendes munkaidő fogalmától a rendkívüli munkaidő fogalmához, amely szerintem jogdogmatikailag nézve két területből áll, azonban az Mt. 107. §-a három területet - amelyek a munkaidő-beosztástól eltérő; a munkaidőkereten felüli vagy az elszámolási időszak alkalmazása esetén az ennek alapjául szolgáló heti munkaidőt meghaladó munkaidő; továbbá az ügyelet tartama - különböztet meg. Megítélésem szerint csak a munkanapokon végzett túlmunka, illetve a munkaszüneti és a pihenőnapokon végzett rendkívüli munkavégzés időtartama a releváns. Mint már szó esett róla, a túlmunkára és a rendkívüli munkaidőben végzett munkára többlethonoráriumot javasol az irányelv. ${ }^{35}$ Arról is szó esett már, hogy az európai államok a túlmunkát átlagosan az alapmunkabér 50\%-ával, míg a pihenőnapon és a vasárnap, valamint az ünnepnapon végzett munkát kétszeres alapmunkabérrel, vagyis az alapmunkabér 100\%-ával díjazzák, ami a munkavállaló kívánságára arányos szabadidőre alakítható. Ezzel szemben az új magyar Mt. szerint a munkáltató és a munkavállaló megegyezésétől, gyakorlatilag azonban a munkáltató akaratától függ, hogy pótlékban vagy szabadidőben részesül a munkavállaló. Ez az új szabályozás ellentétben áll a többségi tagállami és az azzal összhangban álló korábbi magyar szabályozással is, ami szociálisan jelentős hátrányt jelent a munkavállalók számára, mivel a nyugat-európai alapmunkabérekhez viszonyítva alacsony magyarországi alapmunkabérek sok esetben csak a pótlékkal tudnak olyan mértékűvé kiegészülni, amely a nyugat-európai színvonalú megélhetés szerény megközelítésére képes.

Fokozza még ezt a problémát, hogy csak a túlmunkapótlékra maradt az alapbér 50\%-a, míg a vasárnapi rendkívüli munkavégzésre járó pótlék a korábbi 100\%-ról fö szabályként lecsökkent 50\%-ra, és csak akkor 100\%, ha a vasárnap egyúttal heti pihenőnap is. ${ }^{36} \mathrm{~A}$ szombati, vagyis a magyar jog szerint a második teljes pihenőnapra korábban járt szintén $100 \%$-os pótlék viszont - az általános munkarend esetét kivéve - megszünt. Helyette a munkáltató a szombatonként végzett munkaórákat összesítve és azokat összevonva szabadidő kiadásával rendezheti le a munkavállaló szombatonkénti, rendkívüli munkavégzését. ${ }^{37}$

\footnotetext{
35 Az irányelv 18. cikk számmal nem megjelölt, harmadik szövegbekezdése.

36 Lásd a 2012. évi I. törvény 143. § (4) bekezdése.

37 Lásd a 2012. évi I. törvény 105-106. §.
} 


\subsection{Az általános munkarendtől eltérő „müszakos” munkavégzés munkaidőszabályai}

Ezzel szemben viszont az éjszakai müszak után járó pótlék a munkavállalók számára kedvezően változott a 2012-ben hatályba lépett új szabályozás szerint, ami viszont nincsen összhangban az irányelvvel. Az irányelvvel azonban a korábbi Mt. sem állt teljesen összhangban. Míg ugyanis az irányelv csak két müszakot, az éjszakait, és az úgynevezett „váltott müszakot” ismeri, addig a korábbi Mt. önállóan bevezette az éjszakai müszak mellett a 14 órától a 22 óráig tartó délutáni müszakot is, amely után $15 \%$ müszakpótlék járt. Az éjszakai müszakot viszont az irányelvvel összhangban - mint már szó esett róla - 22 órától másnap reggel 6 óráig tartó idötartamban állapította meg, melynek csak teljes vagy olyan ledolgozása esetén járt pótlék, amikor a munkavállaló éjél és az irányelvnek megfelelően másnap reggel 5 , a magyar szabályozás szerint 6 óra között a munkahelyen jelen volt. Ezen az alapon a korábbi Mt. szerint azok, akik hajnal 3 órára mentek dolgozni, a 8 órás munkaidejük első három órájára nem részesültek éjszakai pótlékban. Az új szabályozás ezen változtatott, amikor új alapokra helyezte a müszakpótlék szabályozását. Az új Mt. 141. §-ának (1) bekezdése megszüntette a korábbi 14 és 22 óra közötti délutáni műszakot a vele járó pótlékkal együtt, és helyette - ha a beosztás szerinti napi munkaidő kezdetének időpontja rendszeresen változik - a 18 órától másnap reggel 6 óráig tartó munkaidőt tekinti meghosszabbított éjszakai munkának. Így az éjszakai munkavégzésre járó 30\%-os pótlék munkaórában megállapított arányos részét annak a munkavállalónak is kifizetik, aki pl. helyettesítésként csak egy vagy két órát dolgozott, azért, mert a váltótárs vonata rendszeresen késett. Korábban ilyen esetben az a délutános müszakban dolgozó munkatárs, aki kénytelen volt helyettesítésre mondjuk éjfélig visszamaradni, „ex lege” nem igényelhetett éjszakai műszakpótlékot a munkáltatójától. Ugyanakkor ellentmondást és zürzavart okoz az új Mt. 142. §-a azzal, hogy annak, aki az Mt. 89. §-a szerinti éjszakai műszakban dolgozik, csak $15 \%$ bérpótlék jár. Ezt az ellentmondást csak úgy lehet feloldani, hogy aki állandó jelleggel este 22 óra és másnap reggel 6 óra között dolgozik, annak jár csak $15 \%$-os éjszakai müszakpótlék, míg, aki váltott müszakban dolgozik, annak $30 \%$-os pótlék jár a biológiai életritmus rendszeresen visszatérő és a szervezetet megterhelő változása miatt. Az egyszerủ és helyes szabály az lenne, ha a 18 óra és a másnap 6 óra közötti rendszeres munkavégzésre járna a 15\%-os pótlék, míg a változó éjszaki müszakra a $30 \%$-os.

A váltott müszaknak egy rugalmasított esete, amikor a munkavállaló egymás után két müszakban (a 6 óra utáni első, és a minden további 3 óra után járó pihenőidővel összefüggő megszakitásokat leszámítva) folyamatosan dolgozik. Ebben az esetben a munkavállalónak kétszer 11 óra időtartamú, ha pedig három müszakban dolgozik folyamatosan így, akkor egybefüggően háromszor 11 óra pihenőidő jár. Ez a 22 órás, illetve 33 órás pihenőidő azonban több is lehet azáltal, hogy a heti 40 óra pótlék nélkül, a 48 óra pedig - a munkaidőkeret átlagában - egyáltalán nem léphető túl. Itt meg kell említeni azonban azt is, hogy az EU régi tagállamaiban a túlmunka-órák nemcsak napi munkaidő tekintetében vannak korlátozva, hanem fő szabályként általában oly módon is, hogy heti viszonylatban - föleg egymást követő 
napokon - mennyit lehet végezni. Ugyanakkor viszont a „flexicurity” igényének a kielégítése végett el tudnám képzelni az itt leírt korlátok mellett annak a lehetőségét is, hogy a munkavállaló esetenként napi 16 óra időtartamban is végezhessen túlmunkát, amire azonban legfeljebb heti két alkalommal kerülhessen sor, 30\%-os pótlék és a végzett túlmunkaidő felének megfelelő szabadidő biztosításával. Ennek bevezetése esetén, kivételes módon a napi munkaidő maximuma 16 óra, minimuma pedig 0 óra is lehetne.

Az éjszakai munkának egy speciális esete merülhet fel az olyan váltott müszak esetén, amikor a munkavállaló ennek eredményeként műszakot vált. Ebben az esetben lényegében az irányelvi szabályozás az új Mt. szabályában érvényesül. Az éjszakai müszak ugyanis fő szabályként este 22 órától másnap reggel 6 óráig tart, viszont akkor is jár a lényegében továbbra is - éjszakainak minősíthető - $30 \%$-os müszakpótlék, ha a munkavállaló nem dolgozta végig a teljes müszakot, és éjfélkor vagy reggel 5 órakor, vagy pedig egyik időpontban sem volt jelen a müszakban. Az irányelv 17. cikkének (3) bekezdése adta lehetőség figyelembevételével ez a fő szabályként alkalmazott müszakváltás ugyanakkor variálható is. A legtöbb esetben ez úgy variálódik, hogy 16 órás müszakot követően 24 óra pihenőidő biztosítására kerül sor, vagy pedig 24 órás szolgálatot követően két „szabadnapot” biztosítanak a munkavállaló számára. Mind a két esetben az éjszakai, illetve az este 18 órától másnap reggeli 6 óra közötti időre eső munkavégzés a 30\%-os müszakpótlékkal kerül díjazásra.

Itt még érdemes megjegyezni, hogy váltott müszak esetében - a jelenlegi Mt. 97. §-ának (3) bekezdése szerint, a korábbi Mt.-vel egyezően - a müszak idejének a megváltoztatását egy héttel korábban közölni kell a munkavállalókkal. Ezt a szabályt a korábbi Mt.-nek a 2001. évi, átfogó felülvizsgálata során a kormány igyekezett akként módosítani, hogy a múszak megváltozását az azt megelőző munkahét utolsó napján is elég legyen közölni. E módosítási törekvés akkor általános ellenállást váltott ki a munkavállalók és a szakszervezetek részéről, hiszen a munkavállalók és családtagjaik szabadidős programjának a meghiúsulását idézhette volna elő. Ezért ettől az akkori, első Orbán-kormány kénytelen volt elállni. ${ }^{38}$ Ugyanakkor viszont a nyugat-európai államokban általános gyakorlat, hogy azok a munkavállalók, akik vállalják a munkavégzésre való bármikori rendelkezésre állást, illetve a munkára való behívást, azok magasabb fizetés mellett végzik munkájukat. Ez a kapacitástól függő munkaidőben történő munkavégzés. A magyar jogban csupán a részmunkaidős foglalkoztatásnál vannak erre utaló szabályok. Az új Mt. ugyanis nem tesz különbséget a részmunkaidőben dolgozók között, és nem veszi ki ez alól a szabály alól a 3 éves kor alatti kisgyermeküket nevelő részmunkaidővel foglalkoztatott munkavállalókat. 39

38 A 2001. évi Mt. módosítást előkészítő kodifikációs bizottsági ülésen a MüM jogi osztály vezetője által előterjesztett javaslat, amely végül is nem került a bizottság részéről sem elfogadásra. A javaslat házi sokszorosítással megjelent, de a bizottság tagjainak ellenzéseképpen végül is elvetésre került. Mint a kodifikációs bizottság tagja, magam is elleneztem. Prugberger Tamás-TótH Hilda: A munkaidő, a pihenőidő, a szabadság és a túlmunka munkajogi kérdéseihez. Valóság, 2001/1. 26-27.

39 Vesd össze a 2012. évi I. törvény 61. §-át a 193. §-ával. A munkaviszony a részmunkaidőben dolgozók tekintetében ugyanis nem veszi tekintetbe a 61 . § (3) bekezdésében szereplő részmunkaidővel privilegizált munkavállalóit. 


\section{A kérdés megítélése a pihenőidő kapcsán}

\subsection{A munkaidő viszonya az egyes pihenőidő-formákhoz}

Áttérve a pihenőidőre, az irányelv 2. cikkének 2. bekezdése értelmében pihenőidő az, amikor a munkavállaló nem végez munkát. Ez lényegében negatív meghatározás. Ezzel szemben az Mt. még ilyen fogalommeghatározást sem ad, de nem is szükséges, mert mindenki tisztában van azzal, hogy a pihenőidő az az időszak, amikor a munkavállaló nem végez munkát, és nem is köteles munkát végezni. A pihenőidőt azonban mind az irányelv, mind pedig az Mt. egyaránt három részre tagolja, úgy, mint a napi munkaidőn belüli munkaközi szünet, a két munkanap közötti pihenőidő, valamint a heti pihenőidő vagy pihenőnap.

A 2003/88/EK irányelv 4. cikke a munkaközi szünetröl csak annyit mond, hogy napi 6 óra egybefüggő munkavégzést követően megfelelő pihenőidőt kell biztosítani, aminek mértékét kollektív szerződés vagy a szociális partnerek közötti megegyezés állapítja meg. Ez a szabályozás lényegében megfelel az 1993/104/EK irányelv meghatározásának. E kettőnél azonban sokkal konkrétabb meghatározást adott a 2000/34/EK irányelv megalkotásakor a szociális partnerek megállapodása, amely a tagállamoknál kialakult rendezés szintéziseként ${ }^{40}$ a munkaközi szünet legrövidebb mértékét 20, leghosszabb időtartamát pedig 60 percben állapította meg. Az ennél hosszabb „munkaközi szünet” esetén a napi munkaidőt osztott müszaknak kell minősíteni. Ezt a megoldást vette át már a korábbi Mt., és ezt alkalmazza az új Mt. is.

A pihenőidő irányelvi rendezése meglehetősen hézagos, és a rendezés a szociális partnerek megegyezésére van bízva. Ennek hátránya az, hogy ott, ahol a szakszervezetek gyengék, a munkaközi szünet egészen rövid. A magyar Mt. annyiban jó, hogy 20 percben meghatározza a legrövidebb mértékét. Mivel azonban a 2003/88/ EK irányelv ilyen meghatározást nem tartalmaz, ekörben elég magas a jogszabály megkerülésének a gyakorlata a munkaeröpiacon. A multinacionális vállalatok, különösen a bevásárlóközpontok egy jelentős része, a pénztárosok és az egyszemélyes kiszolgálóhelyeken dolgozó eladók számára, a szakszervezet bevonása nélkül, legfeljebb csak 5 vagy 10 percnyi munkaközi szünetet biztosítanak. ${ }^{41}$

A két nap közötti pihenőidőt az irányelv 3. cikkével egyezően a magyar Mt. 104. $\S$-a is 11 órában állapítja meg. Ezt viszont (a korábbi Mt.-vel egyezően) a folyamatosan és váltott müszakban történő üzemelés, idénymunka, készenlét, valamint a munkavállalónak a munkáltatóval fennálló közeli hozzátartozói viszonya esetén le lehet rövidíteni 8 órára. Bár ezt a lerövidítést az irányelv lehetővé teszi, azonban komoly hátrányt jelent az olyan munkavállalók számára, akik jelentős távolságról (pl. vidékről) kénytelenek munkahelyükre bejárni, és ezáltal a két nap közötti pihenőidejük akár két-három órával csökken.

A heti pihenőidő az Mt. 105. §-a fö szabályként heti két napban (azaz általános munkarend esetén tipikusan a szombati napban és a vasárnapban) állapítja meg. Ez (összesen 48 óra) az irányelvnél sokkal kedvezöbb, ha összehasonlítjuk a már

40 Lásd a 2000/34/EK irányelv 3. cikkét.

${ }^{41}$ Külföldi érdekeltségü áruházi eladóktól és pénztárosoktól kapott bizalmas információ. 
bemutatott 24+11 órás rendezéssel, ahol egybefüggően csak 24 órát kell, vasárnapi napon biztosítani. A szombatra vonatkozó 11 óra a szombati rövidített müszakra vonatkozik, amelyen azonban a nyugat-európai államokban tényleges munkavégzés nem folyik, csak ügyelet van. ${ }^{42} \mathrm{Az}$ ügyelet során pedig nem minden dolgozó van jelen, hanem egymást váltva végzik azt. Így nem minden munkavállalónak kell szombatonként a rövidített munkaidőben megjelenni. Ha viszont valakit a szombati rövidített munkaidőn felül pihenőnapján rendkívüli munkára is berendelnek, akkor azt az időt összevontan kell kiadni. Ezt a megoldást vette át az új Mt. 106. §-a Magyarországon. A korábbi Mt.-vel ellentétben, amely szerint, ha a munkavállaló munkaerejét a munkáltatók a heti szabadidő valamelyik napján rendkívüli munkára igénybe vették, akkor $100 \%$ pótlékra, vagy kívánságukra $50 \%$ pótlékra és szabadidőre voltak jogosultak, az új Mt. 2011. évi júliusi tervezete szerint a munkavállalók a szombati rendkívüli munkavégzés esetén pótlékra nem lettek volna jogosultak, csak szabadidőre, amit a munkáltató bármely munkanapon a többi hétvégi rendkívüli munkavégzéssel együtt összevontan adhatott volna ki. ${ }^{43}$ Ezzel az irányelvhez történő közelítés valósult volna meg a munkavállalók hátrányára. Végül is az Országgyülés által elfogadott új Mt. 143. §-ának (4) bekezdése 100\%-ban állapította meg a heti pihenőnapon történő rendkívüli munkavégzés után járó pótlékot, ha azonban a munkáltató másik pihenőnapot biztosít, a pótlék csak $50 \%$-os mértékü. Lényegében tehát visszatérés történt a korábbi Mt.-ben megfogalmazott megoldáshoz. Végül is a magyar szabályozás e téren megmaradt kedvezőbbnek az irányelvi megoldáshoz viszonyítva. Abban viszont összhangban áll a jelenlegi magyar szabályozás az irányelvvel, hogy a fent már említett esetekben (pl. folyamatos munkavégzés), ha a heti pihenőidőnap vasárnap nem adható ki, akkor egy hónapon belül egy pihenőnapnak vasárnapra kell esnie.

\subsection{A szabadság intézménye a munkaidő szempontjából}

Az évi rendes szabadság mértékét az Mt. 116. §-a szabályozza, kimondva, hogy az alapszabadság 20 munkanap, amely a 25. életévtől kezdődően, általában 3 évenként, az életkor emelkedésével egy-egy nappal nő, és a 45. életévtől kezdődően 10 nap pótszabadság is jár minden munkavállalónak. Az évi rendes szabadság legkisebb mértéke Magyarországon tehát évi 20 munkanap, miközben az irányelv 7. cikke szerint négy hét az éves szabadság legkisebb mértéke. A magyar 5 napos munkahetet figyelembe véve, első látásra úgy tűnik, hogy a hazai szabályozás össz-

42 Kutatásokkal egybekötött külföldi tanulmányútjaimon gyüjtött tapasztalat Németországban, Ausztriában, Svájcban, Franciaországban, Hollandiában és Belgiumban.

43 2011. júl. 18.-i keltezésű sokszorosított „pro domo” jellegű első Mt. tervezet. Az irányelv és ennek alapján, illetve a korábbról is kialakult szokás alapján a nyugat-európai államok csak a vasárnapot kezelik heti pihenőnapként, míg a szombati rövidített munkaidőn túli szabadidőt heti pihenőidőként. Ennek folyományaként az új magyar Mt. első tervezete is a szombati pihenőnapot is „de iure” pihenőidőként kezelte volna, annak ellenére, hogy az is "de facto” hétvégi pihenőnap. Jogdogmatikailag ezzel tudta volna indokolni a magyar jogalkotó, hogy fő szabályként a szombati rendkívüli munkát nem pótlékkal, hanem csak szabadidővel honorálja. A mostani végleges törvényi szabályozás szerint a heti pihenőidő két pihenőnapból áll. 
hangban áll az irányelvvel. Ugyanakkor a jogi szakirodalom (rajtam és Nádas Györgyön kívül még Fodor T. Gábor is) kétségbe vonja ezt a látszólagos összhangot. A már bemutatott magyar szabályozás alapján előfordul, hogy ötnél több munkanap is található az adott, szabadsággal érintett héten. Emiatt (Fodor T. Gábor álláspontja szerint) a 4 heti szabadság helyett a munkavállaló „extrém esetben” csak három hét alapszabadságra válik jogosulttá. ${ }^{4}$

A szabadság mértéke tekintetében tehát nincs összhang az irányelvi és a hazai szabályozás között. Ugyanígy nem áll fenn összhang az úgynevezett szabadságpótlék tekintetében sem, amely 13. havi fizetésként illeti meg a nyugat-európai államok többségében a munkavállalókat, mivel szabadság idején többet költenek, míg a magyar jogban nem létező fogalomról van szó. Összhang van abban, hogy mind a magyar Mt., mind az irányelv tiltja a szabadság pénzben történő megváltását, amire kivételesen és csak akkor kerülhet sor, ha a munkaviszony úgy szünik meg, hogy a munkavállaló nem vette ki még a szabadságát vagy annak egy részét.

A betegszabadságról az irányelv külön nem szól, azonban történelmi tradícióknál fogva a nyugat-európai tagállamok ismerik ezt az intézményt, csakúgy, mint 1992 óta a magyar munkajogi szabályozás is. Csakhogy míg a germán és a frankofon-latin jogrendszerhez tartozó, régi tagállamoknál a betegszabadság általában hat hét, és csak az azonos betegségnek a tárgyévben történő újbóli megjelenése esetén csökken a betegszabadság ideje az előző betegség miatti távolléti napokkal, továbbá a betegszabadság idejére a munkavállalónak átlagkereset jár, addig a magyar Mt. 126. § szerint a betegszabadság időtartama 15 nap, amely idő a tárgyév valamennyi betegsége miatti távolléttel lecsökken. Ezenkívül a betegszabadság idejére díjazásként csak a távolléti díj 70\%-át kapja meg a betegség miatt keresőképtelenné vált munkavállaló.

Az Mt. 127. §-a szabályozza a szülési szabadságot, amelynek időtartama lehetőség szerint a szülést megelőző 4 hét, a szülést követően pedig 20 hét. Sokan a szülést megelőző egy hónapot vagy annak egy részét a szülést követően veszik ki. Ezáltal az 5 hónap meghosszabbodhat. A szülési szabadságról az irányelv nem szól. Az UNICE, a CEEP és az ESZSZ által a szülöi szabadságról kötött keretmegállapodásról szóló, 1996. június 3-i 96/34/EK irányelv azonban az úgynevezett szülői szabadságot rendezi, amely mind a két szülőnek jár a gyermek 8 éves koráig, és mértéke 6 hónaptól 12 hónapig terjedhet, illetve konkrét mértékét az e keret adta lehetőségeken belül az egyes tagállamok nemzeti szabályozással jogosultak megállapítani. Bár ezt az irányelvet a Tanácsnak a BUSINESSEUROPE, az UEAPME, a CEEP és az ESZSZ által a szülői szabadságról kötött, felülvizsgált keretmegállapodás végrehajtásáról és a 96/34/EK irányelv hatályon kívül helyezéséről szóló 2010/18/EU irányelve (2010. március 8.) hatályon kívül helyezte, a régi kontinentális tagállamok többségében továbbra is fenntartották a korábbi szabályok alapján kialakított szülői szabadság rendszerét. A hatályon kívül helyezés lényegében annak érdekében történt, hogy az új tagállamokban letelepedett külföldi cégeknek ne kelljen az anyaországukban az uniós jog szerint kialakult szabályok szerint szülői szabadságot biztosítani. A szülői szabadságot e nyugati államokban továbbra 
is mindkét szülő a saját döntése alapján részletekben veheti ki, és akkor, amikor úgy látja, hogy annak kivétele a gyermek egészséges lelki és/vagy testi fejlődése érdekében szükséges. Itt szükséges megjegyezni, hogy az Mt. 118. §-a egy gyermek után 2 nap, két gyermek után négy nap, további gyermek után összesen 7 munkanap pótszabadságot biztosít mind a két szülő számára, a gyermek 16 éves koráig. Gyulavári Tamás ezt összhangban véli látni az itt említett irányelvi szülői szabadsággall. ${ }^{45}$ Bár e magyar szabályozás szerkezetében teljesen más, mint amit az irányelv tartalmaz, végső esetben azonban felhasználható ama célokra, amelyeket a szülői szabadággal kapcsolatosan az irányelv megjelöl. A magyar szabályozás pozitívumát abban látom, hogy ma már e szabadságot az uniós elöirásnak megfelelően, mind a két szülő számára biztosítja a gyermek 16 éves korának eléréséig.

\begin{abstract}
The paper consists of three parts. The first part introduces the multiple changes - mostly in the favour of employers - in regulation in Hungarian labour law based on the Working Time Directive. The newest idea is also connected to these changes because the reference period may be significantly extended in Hungarian law even a longer period is planned than in the Directive. In the second part I analyse the relevant regulation from a critical point of view pointing out the lack of some clear concepts in the Hungarian regulation. The paper highlights the following: at several employers the workplace and the employees' place of residence were near to each other but nowadays these workplaces are changed and the employees need to take much more time-consuming trips to the actual workplace. The third part examines the relevant case-law of the CJEU.
\end{abstract}

45 GyulaváRI Tamás: A szülői szabadság. In: Kiss György (szerk.): Az Európai Unió munkajoga. Osiris Kiadó, 2001, 135-136. 